\title{
Population Genetic Structure of Laurus nobilis L. Inferred From Transferred Nuclear Microsatellites
}

\author{
By H. Marzouki ${ }^{1,2), 5)}$, N. NAsRi ${ }^{3), 4), 5)}$, B. Jounud ${ }^{3)}$, C. BonneT ${ }^{3)}$, A. Khaldi ${ }^{2)}$, S. Bouzid ${ }^{1)}$ and B. FadY ${ }^{\left.3),{ }^{*}\right)}$
}

(Received $13^{\text {th }}$ October 2008)

\begin{abstract}
Species with fragmented populations and low population size often display low within-population genetic diversity and strong among-population differentiation. Laurus nobilis L. (Lauraceae), common laurel, has a scattered distribution throughout the Mediterranean, with only few autochthonous populations. Our goal was to elucidate if this species has range-wide genetic structure and if planted material can be traced back to its origin. Genetic diversity was investigated using 4 polymorphic nuclear microsatellites (nSSR) transferred from two species of Lauraceae. Sixty-six laurel trees were selected from 7 widely separated populations within the Mediterranean distribution area of the species. A total of 34 alleles (9 alleles per locus on average) were found. Mean genetic diversity within-population $\left(\mathrm{H}_{\mathrm{s}}\right)$, was 0.558. Genetic differentiation among populations $\left(\mathrm{G}_{\mathrm{ST}}=\right.$ 0.243 ) was high compared to that of other angiosperms. Laurus nobilis can be separated into two main gene pools, one from western (Tunisia, Algeria and France) and the other from eastern Mediterranean (Turkey). The Algerian, Tunisian and French populations presented a strong genetic similarity, compatible with the fact that North African laurel populations could be recently introduced from north-western Mediterranean stock.
\end{abstract}

Key words: Laurus nobilis, Nuclear microsatellites, Genetic diversity, Differentiation, Mediterranean.

\section{Introduction}

Laurus nobilis L. (family Lauraceae) is an evergreen tree or shrub commonly known as laurel, bay laurel or sweet bay. These vernacular names denote its most common usage, traditional cooking. In many Mediterranean countries, leaves collected from both cultivated and wild specimens are used for flavoring and as a spice for marinating and pickling foods. Since antiquity, bay leaves have also been used for medicinal purposes in the Mediterranean. The Greeks and Romans used them to treat digestive disorders or viral infections (SAYAH et al., 2002). Recently, their pharmacological properties were confirmed. They include anti-bacterial, anti-fungal, anti-

\footnotetext{
1) Laboratoire de Botanique et de Biologie végétale, Département de Biologie - Faculté des Sciences de Tunis, Tunisia.

2) Unité de Recherche Gestion et Valorisation des Ressources Forestières, INRGREF, Tunis, Tunisia.

3) INRA, UR 629, Ecologie des Forêts Méditerranéennes, Domaine St Paul, Site Agroparc, 84914 Avignon, France.

4) Present address: Laboratoire de Biochimie, Département de Biologie - Faculté des Sciences de Tunis, Tunisia.

5) These authors contributed equally to this article.

*) Correspondence: BRUNO FADY. INRA, UR 629, Ecologie des Forêts Méditerranéennes, Domaine St Paul, Site Agroparc, 84914 Avignon, France. E-mail: fady@avignon.inra.fr
}

diabetes, anti-oxidative and anti-inflammatory effects (MATSUDA et al., 2002; FANG et al., 2005).

Lauraceae are one of the basal angiosperm families with fossils dating back to 100 million years ago (QIU et al., 1999). The genus Laurus is considered as an ancient element of the Tertiary laurifolius flora (QUÉZEL and MÉDAIL, 2003) made of angiosperms (mostly Lauraceae) with large, thick evergreen leaves, which dominated the late Tertiary flora (Miocene and Pliocene, ca. 24 million years). This flora has now almost vanished from the Mediterranean and, except in the Azores, Madeira and the Canary Islands (Macaronesian islands), can only be found in restricted areas under humid and warm climates. Although L. nobilis was initially described using material from Italy and Greece by LINNAEUs (1753), it is considered native only to Turkey (Anatolia) and the Balkan Peninsula by PECH and BRUneton (1982), based on the species alkaloid contents. It is considered as introduced elsewhere in the Mediterranean Basin (BARBERO and QUÉZEL, 1994).

Using AFLP markers, ARROYO-GARCIA et al. (2001) analyzed genetic similarities among different populations of laurel located in the Macaronesian islands, Spain, Italy and France. They separated laurel samples into two distinct groups, one containing samples from Italy and France and the other samples from the Iberian Peninsula and the Macaronesian islands. This indicates that the Pyrenees acted as a strong natural geographic barrier against gene flow during the Pleistocene and that laurel from Spain is more related to laurel in the Macaronesian islands (Laurus azorica (Seub) Franco) than to L. nobilis. A more recent analysis, using chloroplast DNA and populations distributed across the entire Mediterranean Basin, confirmed the existence of separate lineages and challenges the existence of two separate Laurus taxa in the Mediterranean (RoDRIGUEZSANCHEZ et al., 2009).

In this paper, we optimized and used nuclear microsatellite DNA markers (nSSRs) to study the rangewide genetic structure of Laurus nobilis in the Mediterranean Basin. Microsatellites are a form of repetitive DNA first discovered in the early 1980s which have since been recognized as powerful genetic markers for population genetic and phylogeographic studies, combining the useful properties of high mutation rates, co-dominant inheritance when carried by the nuclear genome, and high reproducibility (JARNE and LAGODA, 1996). We addressed the following questions:

- Are L. nobilis populations closely related across their range (due to human dispersal along trade routes) or are they clearly differentiated, as might be expected from their animal-mediated propagule dispersion, 
their Tertiary origin, and the numerous geological and climatic events of late Tertiary and Pleistocene in the Mediterranean (e.g., Messinian salinity crisis and glaciations) that led to their highly fragmented population structure (QUÉzEL and MÉDAIL, 2003)?

- Are non-autochthonous North African L. nobilis populations planted from western (France) or eastern (Turkey) Mediterranean material? And is there an effect of domestication in the form of reduced genetic diversity?

\section{Materials and Methods}

\section{Plant material}

Leaves were sampled from 4-15 Laurus nobilis trees in each of seven populations, including two natural Turkish populations, one cultivated Algerian population, one northern Tunisian population (three natural and 12 cultivated trees) and three natural French populations consisting of 26 samples (Table 1 and Fig. 1). In all populations except in Turkey, all mature individuals in the population were sampled.

\section{DNA isolation}

Leaves were stored at $-20^{\circ} \mathrm{C}$ in a freezer untill DNA isolation, $50 \mu \mathrm{g}$ of fresh tissue per sample were frozen in liquid nitrogen and ground in a grinding mill. Total
DNA was extracted using the QIAGEN Plant DNeasy Mini Kit (Qiagen, Courtabeuf, France).

\section{Microsatellite transfer and optimization}

Using the GenBank database, we screened the family Lauraceae for already developed nSSRs. We selected and tested 16 dinucleotide microsatellite primer pairs from the avocado Persea americana Mill. (SHARON et al., 1997; SCHNELL et al., 2003) and the pondberry Lindera melissifolia Walt. Blume (Еснт et al., 2006). After screening, five primer pairs were usable for our study as they showed DNA amplification consistency. However, LmSI027 appeared monomorphic across all samples. Thus, we used for analysis four microsatellite loci listed in Table 2. Optimization was performed by using a touchdown PCR procedure as indicated below.

\section{Sizing of PCR products}

PCR amplifications were carried out using a PTC-100 (MJResearch, Inc.) thermal cycler in a total volume of $20 \mu \mathrm{L}$. Reactions using "Lindera" primers contained 5-10 ng of genomic DNA, $0.2 \mathrm{mM}$ of each dNTPs, $2 \mathrm{mM}$ of $\mathrm{MgCl}_{2}, 1 \mathrm{nM}$ of each primer, $1 \mathrm{x}$ reaction buffer (Promega - 5x buffer) and 0.1 U. $\mathrm{LL}^{-1}$ of GoTaq polymerase (Promega). Those using "Persea" primers contained $0.25 \mathrm{ng} . \mu \mathrm{L}^{-1}$ of genomic DNA, $0.25 \mu \mathrm{M}$ of each dNTPs, $1.5 \mathrm{mM}$ of $\mathrm{MgCl}_{2}, 0.25 \mu \mathrm{M}$ of each primer, $1 \mathrm{x}$ reaction

Table 1. - Location and description of the Laurus nobilis samples studied.

\begin{tabular}{|c|c|c|c|c|c|c|}
\hline Country & $\begin{array}{l}\text { Pop. } \\
\text { code }\end{array}$ & $\begin{array}{l}\text { Pop. } \\
\text { name }\end{array}$ & $\begin{array}{l}\text { Latitude } \\
\qquad \mathbf{N}\end{array}$ & $\begin{array}{c}\text { Longitude } \\
\mathrm{E}\end{array}$ & $\begin{array}{c}\text { No. of } \\
\text { individuals } \\
\text { analyzed }\end{array}$ & $\begin{array}{c}\text { Population } \\
\text { type }\end{array}$ \\
\hline Algeria & Ak & Akfadou & $36^{\circ} 39^{\prime} 47^{\prime \prime}$ & $4^{\circ} 31^{\prime} 11$ & 05 & $\mathrm{C}$ \\
\hline France & F1 & Cogolin & $43^{\circ} 15^{\prime} 03^{\prime \prime}$ & $6^{\circ} 31^{\prime} 58^{\prime \prime \prime}$ & 11 & $\mathrm{~N}$ \\
\hline France & $\mathrm{F} 2$ & Carcès & $43^{\circ} 28^{\prime} 35^{\prime \prime}$ & $6^{\circ} 11^{\prime} 02^{\prime \prime}$ & 11 & $\mathrm{~N}$ \\
\hline France & F3 & Collobrières & $43^{\circ} 14^{\prime} 17^{\prime \prime}$ & $6^{\circ} 18^{\prime} 33^{\prime \prime}$ & 04 & $\mathrm{~N}$ \\
\hline Tunisia & Tn & North Tunisia & Range $\left(35^{\circ} 57^{\prime}-36^{\circ} 56^{\prime}\right)$ & Range $\left(8^{\circ} 48^{\prime}-10^{\circ} 28^{\prime}\right)$ & 15 & $3 \mathrm{~N}$ and $12 \mathrm{C}$ \\
\hline Turkey & $\mathrm{T} 1$ & Antalya & $36^{\circ} 53^{\prime} 13^{\prime \prime}$ & $30^{\circ} 42^{\prime} 20^{\prime}$ & 10 & $\mathrm{~N}$ \\
\hline Turkey & $\mathrm{T} 2$ & Manavgat & $36^{\circ} 47^{\prime} 20^{\prime \prime}$ & $31^{\circ} 26^{\prime} 40^{\prime \prime}$ & 10 & $\mathrm{~N}$ \\
\hline
\end{tabular}

Population type:

$\mathrm{C}=$ cultivated

$\mathrm{N}=$ Natural

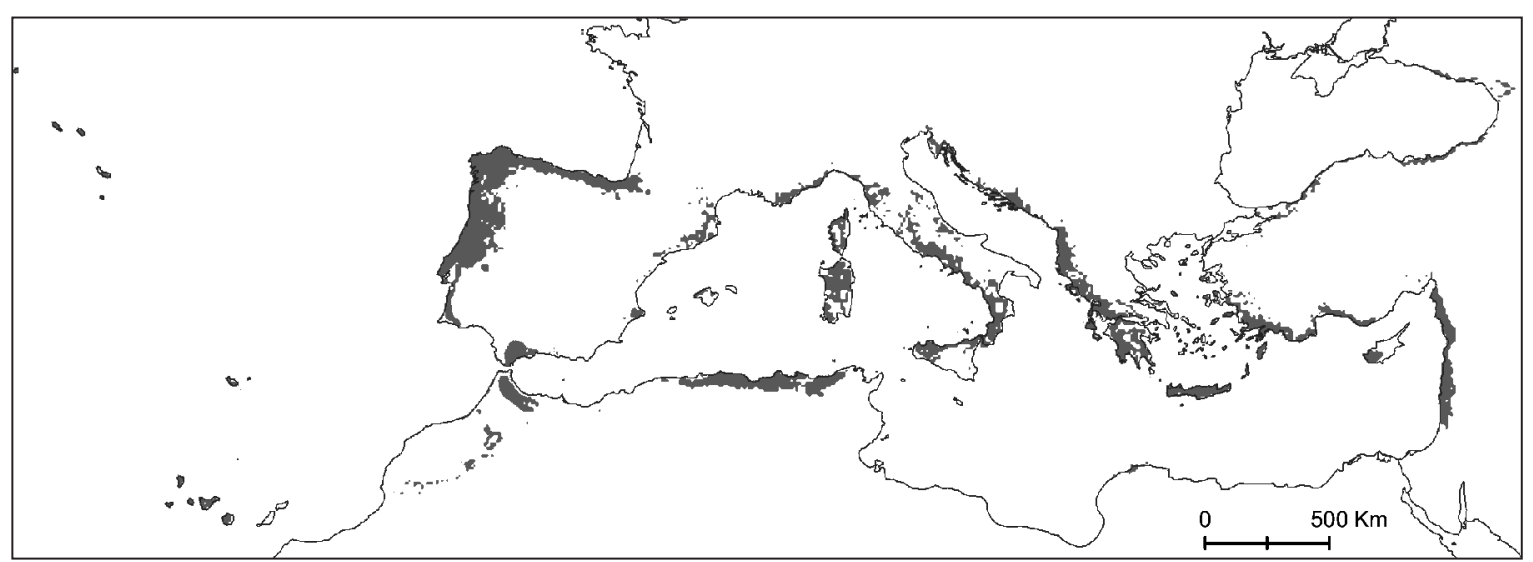

Figure 1. - Geographic distribution (in shaded grey) of Laurus azorica (Seub) Franco (Macaronesia and southern Morocco) and Laurus nobilis L. across the Mediterranean Basin. Map redrawn from RodRiguez-SANCHEZ et al., 2009. 
buffer (Promega - 5x buffer) and 0.025 U. $\mu L^{-1}$ of GoTaq polymerase (Promega).

For the AVAG03 primers, touchdown PCR conditions were as follows: $4 \mathrm{~min}$ at $94^{\circ} \mathrm{C}$ as the initial denaturation step, followed by 33 cycles of $30 \mathrm{~s}$ at $94^{\circ} \mathrm{C}$ denaturation, 1 min at $60^{\circ} \mathrm{C}$ decreasing $0.5^{\circ} \mathrm{C}$ per cycle and 1 min extension at $72^{\circ} \mathrm{C}$, with a final extension step of $72^{\circ} \mathrm{C}$ for $8 \mathrm{~min}$. For the AVAC01 primers, the standard PCR profile was as follows: $4 \mathrm{~min}$ at $94^{\circ} \mathrm{C}$ as the initial denaturation step, followed by 33 cycles of $30 \mathrm{~s}$ at $96^{\circ} \mathrm{C}$ denaturation, $1 \mathrm{~min}$ at $48^{\circ} \mathrm{C}$ and $1 \mathrm{~min}$ extension at $72^{\circ} \mathrm{C}$, with a final extension step of $72^{\circ} \mathrm{C}$ for $7 \mathrm{~min}$. For the "Lindera" primers, PCRs profiles were identical to those described by EcHT et al. (2006).

After amplification, PCR products were mixed to a loading buffer (98\% formamide, $10 \mathrm{mM}$ EDTA pH 8.0, $0.1 \%$ bromophenol blue, $0.1 \%$ xylene cyanol and $10 \mathrm{mM}$ $\mathrm{NaOH}$ ), heated $5 \mathrm{~min}$ at $95^{\circ} \mathrm{C}$ and then set on ice. Amplification fragments were electrophoretically separated on a $6 \%$ polyacrylamide gel and stained using silver nitrate (RAJORA et al., 2000). To avoid possible scoring and mistyping errors, each PCR product was genotyped twice on different gels and electrophoretic profiles were scored 3 times by 3 different people.

\section{Statistical analysis}

As loci were transferred from related species and not designed specifically for Laurus nobilis, we expected the presence of null alleles (ODDOU-MURATORIO et al., 2009). We used the software MICRO-CHEKER (VAN OOSTERHOUT et al., 2004) to test for the presence of null alleles in all our populations. Allelic frequency, allelic richness and population structure estimates $\left(\mathrm{F}_{\mathrm{is}}, \mathrm{G}_{\mathrm{st}}, \mathrm{D}_{\mathrm{st}}\right.$, pairwise differentiation tests) were calculated using the FSTAT program (GOUDET, 1995). Significance of differentiation estimates was tested by performing 1000 randomizations (genotypes among samples) as implemented in FSTAT. The program POPULATIONS (http://bioinformatics.org/ tryphon/populations/) and mean pairwise genetic distances (NEI, 1987) were used for constructing a dendrogram using the UPGMA approach. Significance of tree topology was assessed with 1000 bootstraps over loci. The dendrogram was plotted using program TREEVIEW (http://taxonomy.zoology.gla.ac.uk/ rod/treeview.html). The analysis of molecular variance (AMOVA) procedure was accomplished using GENALEX and two different estimates of differentiation, $F_{s t}$ and $R_{s t}$ (Peakall and Smouse, 2006). We also conducted a Principal Component Analysis (PCA) using GENALEX based on NEI (1987) genetic distance computed from nuclear SSR frequencies. Finally, we tested the existence of a correlation between genetic diversity and geographic distance using a Mantel test as implemented in GENALEX.

\section{Results}

Microsatellite polymorphism and genetic diversity within population

Four microsatellites gave reliable amplification products differing by either two bases or multiples of two for each allele. As these 4 loci were shown to be dinucleotidic repeat types in avocado and pondberry (SCHNELl et al., 2003; ECHT et al., 2006), we considered that they also were dinucleotide nSSRs in L. nobilis. We never detected any double null-homozygotes, which suggests that there are actually no null alleles in our data set. This was confirmed by the output of MICROCHECKER.

The total number of alleles at the 4 loci was 36 and varied from 2 (AVAC01) to 17 (LmSI002) with an average of 9 alleles per locus (Table 2). All Algerian, French and Tunisian populations were fixed for one allele in AVAC01 whereas Turkish populations were fixed for the other allele. Mean total genetic diversity $\left(\mathrm{H}_{\mathrm{t}}\right)$ was 0.738 and mean within-population diversity $\left(\mathrm{H}_{\mathrm{s}}\right)$ was 0.558 . Mean allelic richness per population $(\mathrm{R})$ varied from 2.00 to 3.86 . Number of alleles and gene diversity per locus in Laurus nobilis were not correlated to those found in the species for which the microsatellites had been originally designed (Table 2 ).

Except for population F3 where two individuals carried identical genotypes, all individuals in the spontaneous populations were made up of different genotypes, i.e. not derived from each other by vegetative propagation. There was a significant heterozygote excess denot-

Table 2. - Microsatellite loci and primers used in the analysis of Laurus nobilis L. populations.

\begin{tabular}{|c|c|c|c|c|c|c|c|c|c|}
\hline Reference & Locus & Repeat & Forward and reverse primers $\left(5^{\prime}-3^{\prime}\right)$ & $\begin{array}{l}\text { Size range } \\
\text { (bp) }\end{array}$ & $\begin{array}{l}\text { Annealing } \\
\text { temp }\left({ }^{\circ} \mathrm{C}\right)\end{array}$ & $\begin{array}{c}\text { Original } \\
\text { nb of } \\
\text { alleles }\end{array}$ & $\begin{array}{l}\text { Nb of } \\
\text { alleles in } \\
\text { L. nobilis }\end{array}$ & $\begin{array}{l}\text { Mean } \\
\text { original } \\
\text { gene } \\
\text { diversity }\end{array}$ & $\begin{array}{c}\text { Mean } \\
\text { gene } \\
\text { diversity } \\
\text { in } L . \\
\text { nobilis }\end{array}$ \\
\hline L. melissifolia* & $\mathrm{LmSI002}$ & $(\mathrm{AC})_{27}$ & $\begin{array}{l}\text { ATA ATG CCT CTT GCT TAG GC } \\
\text { TTC AAC TTG ATT GAG GAC ATC }\end{array}$ & 171 & 50 & 11 & 17 & 0.87 & 0.79 \\
\hline L. melissifolia* & LmSI004 & $(\mathrm{AC})_{10}(\mathrm{~A})_{9}$ & $\begin{array}{l}\text { CCA CTT GTG AAT AAT CCA ATC } \\
\text { GTG ACA AAC TAA GAA TAT TGC AC }\end{array}$ & 255 & 50 & 2 & 8 & 0.06 & 0.73 \\
\hline L. melissifolia* & $\mathrm{LmSIO} 27 * * *$ & $(\mathrm{AC})_{13}$ & $\begin{array}{l}\text { CTA AGA AGT GTC CAA GTT AGT C } \\
\text { CCA TGG ATA CTC CAT TGG TA }\end{array}$ & 214 & 50 & 2 & 1 & 0.21 & 0.00 \\
\hline$P$. americana** & AVAG03 & $(\mathrm{TC})_{17}$ & $\begin{array}{l}\text { GCA CTT CCT AAA CTT GCA GGT } \\
\text { CTG AAC ATC CAA TGA CAA ACA TCC }\end{array}$ & $92-122$ & 48 & 14 & 9 & 0.84 & 0.71 \\
\hline P. americana** & AVACO1 & $(\mathrm{TG})_{15}$ & $\begin{array}{l}\text { CTG GTT GCT CTC TTG TCT ACA TAA TA } \\
\text { CGG TTT TGT AAG TTG ATA G }\end{array}$ & $95-185$ & 45 & 16 & 2 & 0.86 & 0.00 \\
\hline
\end{tabular}

\footnotetext{
* as described by EcHT et al. (2006).

** as described by SCHNELL et al. (2003).

*** not used for analyses.
} 
Table 3. - Gene diversity per locus and population $(\mathrm{H})$, overall mean expected heterozygosity $\left(\mathrm{H}_{\mathrm{s}}\right)$, mean number of alleles (A), mean rarefied allelic richness (R) based on a minimum sample size of 4 diploid individuals per population and within population estimation of departure from Hardy Weinberg equilibrium $\left(\mathrm{F}_{\text {is }}\right)$.

\begin{tabular}{|c|c|c|c|c|c|c|c|c|}
\hline \multirow[t]{2}{*}{ Pop. code } & \multicolumn{4}{|c|}{$\mathrm{H}$} & \multirow{2}{*}{$\mathrm{H}_{\mathrm{s}}$} & \multirow{2}{*}{ A } & \multirow{2}{*}{$\mathrm{R}$} & \multirow{2}{*}{$\mathrm{F}_{\text {is }}$} \\
\hline & (LmSI02) & (LmSI04) & (AVAG03) & (AVAC01) & & & & \\
\hline $\mathbf{A k}$ & 0.500 & 0.650 & 0.700 & 0.000 & 0.425 & 2.50 & 2.39 & $-0.189 \mathrm{~ns}$ \\
\hline F1 & 0.895 & 0.786 & 0.518 & 0.000 & 0.528 & 5.50 & 3.52 & $-0.116 *$ \\
\hline F2 & 0.850 & 0.773 & 0.714 & 0.000 & 0.563 & 4.50 & 3.40 & $-0.206^{* *}$ \\
\hline $\mathbf{F 3}$ & 0.500 & 0.583 & 0.750 & 0.000 & 0.391 & 2.00 & 2.00 & $0.045 \mathrm{~ns}$ \\
\hline Tn & 0.893 & 0.862 & 0.750 & 0.000 & 0.605 & 6.25 & 3.86 & $0.015 \mathrm{~ns}$ \\
\hline T1 & 0.906 & 0.789 & 0.794 & 0.000 & 0.595 & 5.25 & 3.83 & $-0.125 *$ \\
\hline $\mathbf{T} 2$ & 0.906 & 0.683 & 0.783 & 0.000 & 0.568 & 5.00 & 3.53 & $-0.138 *$ \\
\hline
\end{tabular}

*: significant at the $5 \%$ confidence level.

**: significant at the $1 \%$ confidence level.

ns: non significant.

$\mathrm{H}_{\mathrm{s}}$ was calculated using GenAlEx.

ed by significantly negative $\mathrm{F}_{\text {is }}$ observed in all the spontaneous populations, except for F3, and none in planted populations (Table 3).

\section{Among population gene diversity}

Mean diversity among populations, $\mathrm{D}_{\text {st }}$, was 0.179 . The proportion of gene differentiation residing among populations was significant $\left(\mathrm{G}_{\mathrm{st}}=0.243, \mathrm{p}<0.001\right) . \mathrm{G}_{\mathrm{st}}$ among western Mediterranean populations (excluding Turkey) was $0.108(\mathrm{p}<0.001)$. All pair-wise differentiation tests among western Mediterranean populations (France, Tunisia and Algeria) were non-significant, as was the only test that could be performed between the two Turkish populations. However, all pair-wise differentiation tests were significant when they compared a western Mediterranean population with a Turkish population (data not shown). The UPGMA dendrogram identified two significantly different phylogenetic groups supported by strong bootstrap values, one including samples from France, Tunisia and Algeria, i.e. western Mediterranean and the other including two populations from Turkey i.e. eastern Mediterranean (Fig. 2). Within the western Mediterranean, bootstrap values were lower, except between the Tunisian population and one French population.

The AMOVA procedure on allele frequencies indicated that $33 \%$ of the total variation occurred among the eastern (samples from France, Tunisia and Algeria) and western (the two populations from Turkey) Mediterranean groups, 5\% was among populations within regions, and $62 \%$ remained among individuals within populations (significant $\mathrm{F}_{\mathrm{st}}, \mathrm{p}<0.01$ ). When microsatellite length was taken into consideration, differences among populations within regions became non-significant, and the total genetic variation (significant $R_{\text {st }}$, $\mathrm{p}<0.01)$ was due to between-region $(31 \%)$ and amongindividual within-population $(69 \%)$ variations.

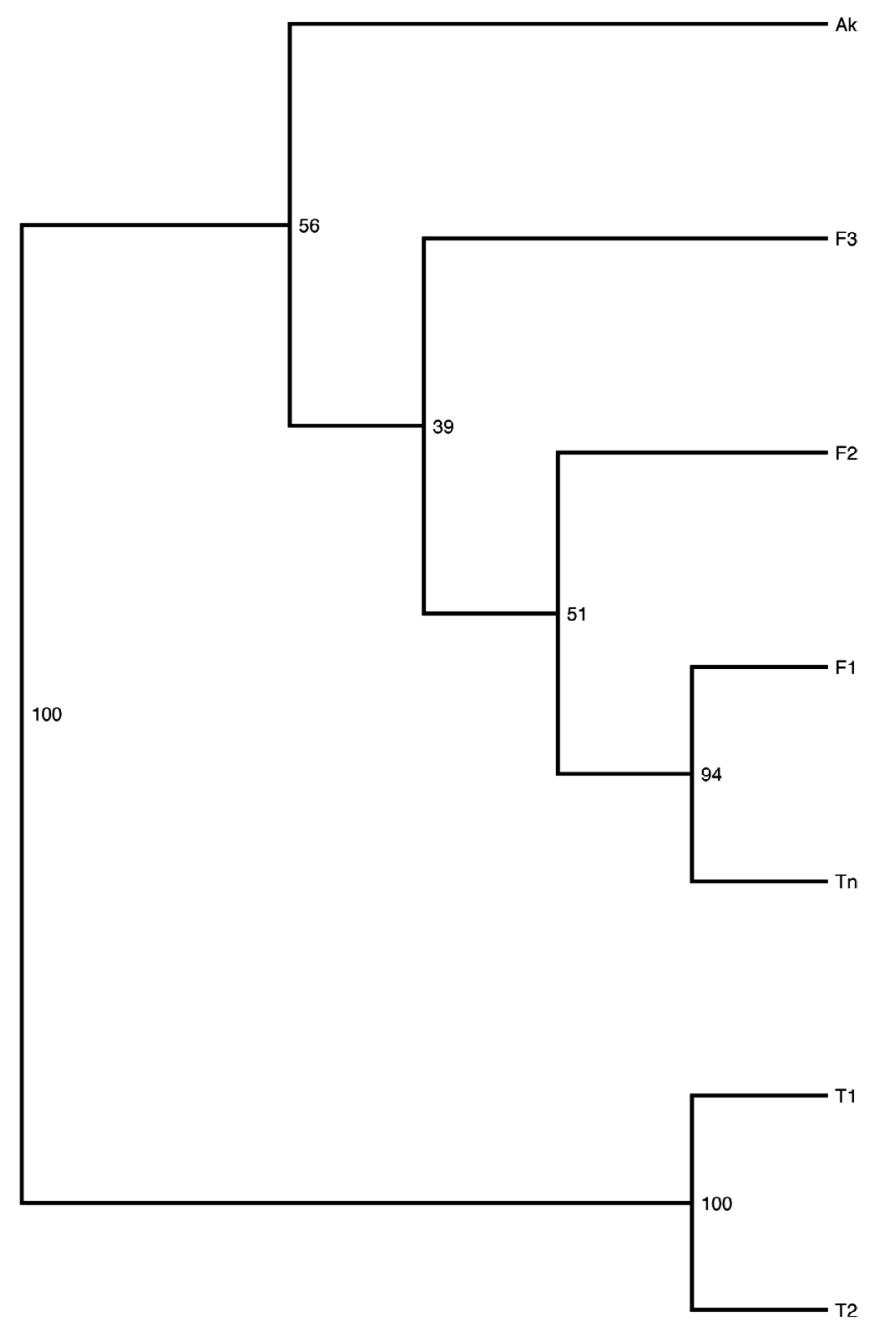

Figure 2. - Unrooted UPGMA tree for Laurus nobilis, based on NEI (1987) genetic distance computed from nuclear SSRs frequencies (see Table 1 for population codes) and 1000 bootstraps over loci. Numerical values at nodes represent the significance (in percent) of the topology. 


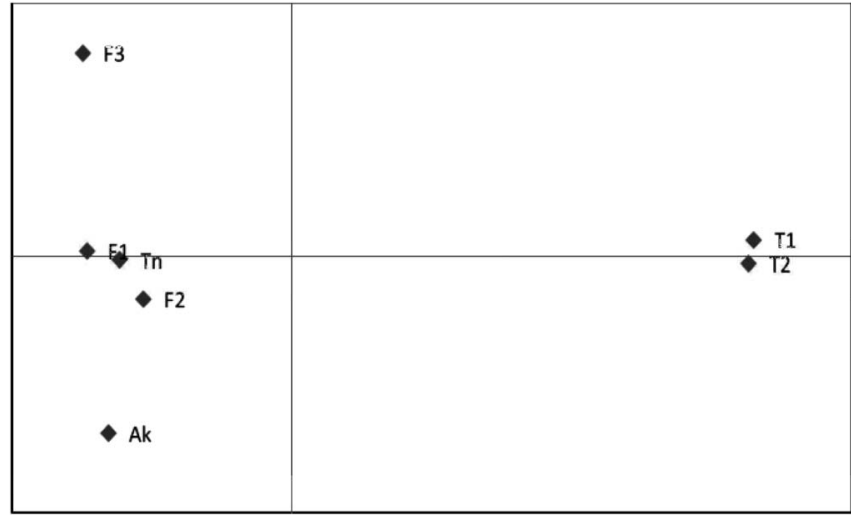

Figure 3. - Plot of the first two components of the standardized PCA for Laurus nobilis, based on NEI (1987) genetic distance computed from nuclear SSRs frequencies (see Table 1 for population codes).

The population structure identified from the PCA is shown in Figure 3. Loadings of NEI (1987) genetic distance on the first six PC axes are reported in Table 4. The first two PC axes accounted for $65.82 \%$ and $17.72 \%$ of the total variation, respectively. They clearly separated two main groups of populations: one included samples from France, Tunisia and Algeria, i.e. western Mediterranean and the other included the two populations from Turkey i.e. eastern Mediterranean. When populations were regrouped into 3 "super-populations" (Turkey, North Africa and France) to increase sample size, the first PC axis accounted for $93.55 \%$ of the total variability.

There was a significant correlation between genetic distance and geographic distance (Mantel test, $\mathrm{r}^{2}=0.822$, $\mathrm{p}$-value $=0.030$, data not shown) when all populations were considered, although this correlation was due to the existence of two separate groups of points (within the eastern and western Mediterranean groups on the one hand, and among the two groups on the other hand). Allelic richness was not significantly different between the eastern $(R=3.678)$ and western $(R=3.034)$ Mediterranean population groups. It was not significantly different between North Africa $(\mathrm{R}=3.124)$ and France $(\mathrm{R}=2.974)$.

\section{Discussion}

We optimized a new set of 4 polymorphic nSSRs for Laurus nobilis, which can be used for population genetic studies in $L$. nobilis in addition to already available chloroplast SSRs (WEISING and GARDNER, 1999) and AFLPs (ARROYO-GARCIA et al., 2001). The transferability of nuclear SSRs from the two Lauraceae Persea americana and Lindera melissifolia to Laurus nobilis is $31.25 \%$ (5 loci out of 16 although one is monomorphic). This rate remains low in comparison to other angiosperm species. For example, GLAUBITz et al. (2001) were able to transfer six dinucleotide microsatellites to Eucalyptus symphyomyrtus from eight developed in E. sieberi (transferability of $75 \%$ ). Sото et al. (2003) were also able to transfer six microsatellites to the two oak species Quercus ilex and $Q$. suber from eight developed in Quercus macrocarpa and Q. petraea. However, as allelic and gene diversities of original species were not correlated to values found in $L$. nobilis, primer selection in the original species should not bias genetic diversity parameters in $L$. nobilis.

Within population genetic diversity in $L$. nobilis (Mean gene diversity $\mathrm{H}_{\mathrm{t}}=0.58$, mean number of alleles per population $\mathrm{A}=9$ ) was comparable to that found in pondberry $\left(\mathrm{H}_{\mathrm{t}}=0.61, \mathrm{~A}=6\right.$; ECHT et al., 2006) and lower than that found for avocado $\left(\mathrm{H}_{t}=0.830, \mathrm{~A}=18.8\right.$; SCHNELl et al., 2003). Pondberry has a restricted distribution in fragmented patches, although avocado is widespread, but cultivated. Whereas no comprehensive review exists to our knowledge, gene diversity values found in angiosperm woody species typically ranged from 0.70 to 0.80 (e.g. Fagaceae, VALBUENA-CARABANA $e t$ al., 2008; Rosaceae, FARWIG et al., 2008; Leguminosae, LACERDA et al., 2008). More generally, habitat fragmentation is associated with a reduction of genetic diversity within populations (KAWATA, 1997). Hence, low diversity in common laurel could be linked to ist fragmented and patchy distribution as well.

Heterozygotes excess was significant in all spontaneous populations except the one population where sample size was smallest $(\mathrm{N}=2)$ and two individuals had the same genotypes. The existence of two identical genotypes within a single population is statistically unlikely and could indicate that Laurus nobilis uses vegetative propagation as a way to reproduce in natural conditions. An excess of heterozygotes may be an indication of selection against homozygotes, either because heterozygotes have better fitness at linked loci or because of purging of deleterious alleles (HANSSON and WESTERBERG, 2002), as often suggested in forest trees (e.g. LEDIG et al., 1983)

The proportion of genetic differentiation residing among Laurus nobilis populations in our study $\left(\mathrm{G}_{\mathrm{st}}=\right.$ 0.243), is in the higher range of values found for angiosperms. PETIT et al. (2005) reported that average

Table 4. - Loadings of NEI (1987) genetic distances on the first six PC axes.

\begin{tabular}{lrrrrrr}
\hline Axis & PC1 & PC2 & PC3 & PC4 & PC5 & PC6 \\
\hline F1 & -0.110 & 0.005 & -0.008 & -0.071 & 0.024 & -0.029 \\
Tn & -0.092 & -0.002 & 0.002 & -0.029 & -0.035 & 0.053 \\
Ak & -0.098 & -0.138 & 0.075 & 0.031 & 0.003 & -0.010 \\
F2 & -0.080 & -0.033 & -0.118 & 0.036 & 0.000 & -0.007 \\
F3 & -0.112 & 0.160 & 0.041 & 0.036 & 0.006 & -0.005 \\
T1 & 0.247 & 0.013 & 0.006 & -0.005 & -0.047 & -0.028 \\
T2 & 0.245 & -0.005 & 0.002 & 0.003 & 0.049 & 0.027 \\
\hline EigenValne & 0.170 & 0.046 & 0.021 & 0.009 & 0.006 & 0.005 \\
\hline
\end{tabular}


angiosperm $\mathrm{G}_{\mathrm{st}}$ for bi-parental nuclear markers was 0.184 . In L. nobilis, more than $30 \%$ of the genetic variation is found between eastern and western Mediterranean populations. Although our sample size is quite low, our data point to the existence of at least two different gene pools in the Mediterranean, rather than to an isolation-by-distance mechanism (although the result of the Mantel test was significant), thus confirming the results of RODRIGUEZ-SANCHEZ et al. (2009). L. nobilis is an ancient element of the Tertiary Mediterranean flora, with typical tropical-like ecological requirements, and has since receded to small and isolated patches of forests with suitable high temperature and humidity conditions throughout the Mediterranean (QUÉZEL and MÉDAIL, 2003). Its population groups have thus possibly been separated for thousands of generations, for which our genetic data can be a plausible signature. However, eastern Mediterranean populations did not demonstrate higher gene diversity than western Mediterranean ones, as found for conifers and attributed to the paleo-climatic events of the latest glacial cycle (i.e. colder climate in the western than in the eastern Mediterranean, FADY, 2005). Additional populations would be needed to verify if this result indicates an equally reduced ecological niche on both sides of the Mediterranean Basin during the Late Glacial Maximum or current particular environmental conditions (e.g. local human impact). Additional populations, including Laurus azorica, would also be needed to verify if the high level of differentiation measured between eastern and western populations indicates ongoing speciation.

Laurus nobilis is not described as native to North Africa (QuÉzEL and MÉDAIL, 2003). The very close genetic proximity between our North African and French samples could be an indication that they all derive from north-western Mediterranean populations, and not from eastern Mediterranean populations. Although not tested here, an Iberian origin for the North African germplasm seems unlikely, as differentiation between Iberian and French-Italian material was found to be very high by ARroyo-Garcia et al. (2001). A likely origin for our North African material could thus be either France or (/and) Italy. However, this does not provide any indication as to when L. nobilis may have been introduced into North Africa, as trade routes between the Western Mediterranean and North Africa were frequent over the centuries. Considering the low, non significant level of differentiation between French and North African samples, and the fact that the North African material does not appear bottlenecked (no significant difference in allelic richness between French and North African material), it is possible that introductions from different populations occurred repeatedly throughout history.

\section{Acknowledgment}

We thank M. Mohand Messaoudene from 'Institut National de la Recherche Forestière', Tizi-Ouzou, for sample collection in Algeria and M. MELAHAT SAHIN from Southwest Anatolia Research Institute, Antalya, for sample collection in Turkey.

\section{References}

Arroyo-Garcia, R., J. M. Martinez-Zapater, J. A. FerNANDEZ PRIETO and R. Alvarez-Arbesu (2001): AFLP evaluation of genetic similarity among laurel populations. Euphytica 122, 155-164.

Barbero, M. and P. Quezel (1994): Place, rôle et valeur historique des éléments laurifoliés dans les végétations préforestières et forestières ouest-méditerranéennes. Annales di Botanica, 52, 81-133.

EChT, C. S., D. DeEMer, T. KBisiaK and C. D. NeLson (2006): Microsatellites for Lindera species. Molecular Ecology Notes 6, 1171-1173.

FADY, B. (2005): Is there really more biodiversity in Mediterranean forest ecosystems? Taxon $\mathbf{5 4}$ (4), 905-910.

FAng, F., S. SAng, K. Y. Chen, A. Gosslau, C. Ho and R. T. Rosen (2005): Isolation and identification of cytotoxic compounds from Bay leaf (Laurus nobilis). Food Chemistry 93, 497-501.

FARWig, N., C. Braun and K. Boehning-Gaese (2008): Human disturbance reduces genetic diversity of an endangered tropical tree, Prunus africana (Rosaceae). Conservation genetics 9 (2), 317-326.

Glaubitz, J. C., L. C. Emebiri and G. F. Moran (2001): Dinucleotide microsatellites from Eucalyptus sieberi: inheritance, diversity, and improved scoring of singlebase differences. Genome 44, 1041-1045.

GOUDET, J. (1995): Fstat version 1.2. A computer program to calculate F-statistics. Journal of Heredity 86, $485-486$.

HANsson, B. and L. Westerberg (2002): On the correlation between heterozygosity and fitness in natural populations. Molecular Ecology 11 (12), 2467-2474.

JARNE, P. and P. J. L. LAGODA (1996): Microsatellites, from molecules to populations and back. Trends in Ecology and Evolution 11: 424-430.

KAWATA, M. (1997): Loss of genetic variability in a fragmented continuously distributed population. Population Ecology 39 (2), 227-237.

Lacerda, A. E. BD., M. Kanashiro and A. M. SebBenn (2008): Effects of reduced impact logging on genetic diversity and spatial genetic structure of a Hymenaea courbaril population in the Brazilian Amazon Forest. Forest Ecology and Management 255 (3/4), 1034-1043.

Ledig, F. T., R. P. GuRIES and B. A. BonefELd (1983): The relation of growth to heterozygosity in pitch pine. Evolution 37 (6), 227-1238.

Linnaeus, C. (1753): Ray Society. Species Plantarum. Facsimile of the first edition of 1753 published by Bernard Quaritch Ltd. in 1857.

Matsuda, H., H. Shimoda, K. NinomiYa and M. YoshiKawa (2002): Inhibitory mechanism of costunolide, a sesquiterpene lactone isolated from Laurus nobilis, on blood-ethanol elevation in rats: involvement of inhibition of gastric emptying and increase in gastric juice secretion. Alcohol and Alcoholism 37, 121-127.

NEI, M. (1987): Molecular evolutionary genetics. Columbia University Press, New York

Oddou-Muratorio, S., G. G. Vendramin, J. Buiteveld and B. FADY (2009): Population estimators or progeny tests: what is the best method to assess null allele frequencies at SSR loci? Conservation Genetics, online First.

PeAkall, R. and P. E. SMOUse (2006): GENALEX 6: genetic analysis in Excel. Population genetic software for teaching and research. Molecular Ecology Notes 6, 288-295. 
PeCh, B. and J. BRUneton (1982): Alcaloïdes du laurier noble, Laurus nobilis. Journal of Natural Product 45 , 560-563.

Petit, R. J., J. Duminil, S. Fineschi, A. Hampe, D. SAlvini and G. G. VENDRAMIN (2005): Comparative organization of chloroplast, mitochondrial and nuclear diversity in plant populations. Molecular Ecology 14, 689-701.

QiU, Y. L., J. Lee, F. Bernasconi-Quadroni, D. E. Soltis, P. S. Soltis, M. Zanis, E. A. Zimmer, Z. Chen, V. Savolainen and M. W. Chase (1999): The earliest angiosperms: evidence from mitochondrial, plastid and nuclear genomes. Nature 402, 404-407.

QuÉzEL, P. and F. MÉDAIL (2003): Ecologie et biogéographie des forêts du bassin méditerranéen. Elsevier (Collection Environnement), Paris, 573 p.

Rodríguez-Sánchez, F., B. Guzmán, A. Valido, P. Vargas and J. Arroyo (2009): Late Neogene history of the laurel tree (Laurus L., Lauraceae) based on phylogeographical analyses of Mediterranean and Macaronesian populations. Journal of Biogeography, online first.

SAYAH, M., J. VAlizAdEH and M. KAMALINEJAD (2002): Anticonvulsant activity of the leaf essential oil of Laurus nobilis against pentylenetetrazole- and maximal electroshock-induced seizures. Phytomedicine 9, 212-216.
Schnell, R. J., J. S. Brown, C. T. Olano, E. J. Power and C. A. KROL (2003): Evaluation of avocado germplasm using microsatellite markers. The American Society for Horticultural Science 128 (6), 881-889.

Sharon, D., P. B. Cregan, S. Mhameed, M. Kusharska, J. HiLlel, E. LAHAV and U. LAVI (1997): An integrated genetic linkage map of avocado. Theoretical Applied Genetics 95, 911-921.

Soto, A., Z. LoREnzo and L. GIL (2003): Nuclear microsatellite markers for the identification of Quercus ilex L. and Q. suber L. hybrides. Silvae Genetica 52 (2), 63-66.

Van Oosterhout, C., W. F. Hutchinson, D. P. M. Wills and P. SHIPLEY (2004): MICRO-CHECKER: software for identifying and correcting genotyping errors in microsatellite data. Molecular Ecology Notes 4, 535-538.

Valbuena-Carabana, M., S. C. Gonzalez-Martinez and L. GIL (2008): Coppice forests and genetic diversity: A case study in Quercus pyrenaica Willd. from Central Spain. Forest Ecology and Management 254, 225-232.

WEISING, K. and R. C. GARDNER (1999): A set of conserved PCR primers for the analysis of simple sequence repeat polymorphisms in chloroplast genomes of dicotyledonous angiosperms. Genome 42, 9-19.

\title{
Transfer of Microsatellite Loci For The Tropical Tree Prunus africana (Hook. f.) Kalkman
}

\author{
By S. CAVERS ${ }^{\left.1,{ }^{*}\right)}$, R. C. MunRo ${ }^{1)}$, C. A. C. KADU ${ }^{2)}$ and H. KonRAD ${ }^{2)}$ \\ (Received $27^{\text {th }}$ October 2008)
}

\begin{abstract}
Using databases of previously published primers, we optimised six nuclear microsatellite markers for Prunus africana for the purposes of studying spatial genetic structure and gene flow. To assess variability, these and three previously transferred loci were screened in populations from Kenya and South Africa. Across both popu-

\footnotetext{
1) Centre for Ecology \& Hydrology, Bush Estate, Penicuik, Midlothian, EH26 0QB, UK.

2) Federal Research and Training Centre for Forests, Natural Hazards and Landscape Department of Genetics Unit of gene conservation and nurseries, A-1140 Wien, Hauptstraße 7, Austria.

*) Correspondence: Stephen CAVers, Tel: +44 131445 8552, Fax: +44 131445 3943. E-mail: scav@ceh.ac.uk
}

lations most loci were polymorphic, with the exception of a single locus which failed to amplify in the South African samples, exhibiting between 2 and 22 alleles and levels of expected heterozygosity $(\mathrm{He})$ ranged from 0.059 to 0.932 . Departures from Hardy-Weinberg equilibrium were detected for all loci but not for all populations. The estimated null allele frequency was very low to moderate and no evidence for linkage disequilibrium was detected.

Key words: Prunus africana, nuclear microsatellites, gene flow, genetic diversity.

\section{Introduction}

The African tree species, Prunus africana (Hook. f.) Kalkman (Rosaceae), also known as the African Cherry, 